\title{
Analysis on Teaching Measures of Logistics Management Major in Applied Universities from the Perspective of Supply-side Reform
}

\author{
Yujie Zuo
}

Acknowledgement:

Applied demonstration course of Chifeng University in 2019: Modern Logistics 20190404

Abstract: Under the background of supply-side reform, colleges and universities pay attention to the cultivation of application-oriented talents to meet the needs of social development. Taking the logistics management major of colleges and universities as an example, teaching reform measures are proposed from the background of supply-side reform.

Keywords: supply-side reform; applied talents; logistics management major; teaching measures

my country's "supply-side reform" was proposed for the first time at the 2015 Central Financial and Economic Leadership Group meeting. Since then, my country has entered the stage of industrial restructuring. Various industries have started to improve the supply system with the idea of "supply-side reform". Efficiency and quality. Nowadays, all colleges and universities are committed to cultivating practical talents and application-oriented talents. Therefore, colleges and universities must establish a teaching concept of serving the society, understand the needs of enterprises from the background of supply-side reforms, and cultivate talent quality, knowledge and skills. To meet the needs of enterprises for talents.

\section{Problems in the teaching of logistics management in colleges and universities}

\subsection{Low practical teaching credits}

The practical teaching of logistics management major in my country's colleges and universities mainly includes cognitive internships, simulated internships, work internships, curriculum design, graduation thesis, graduation internships, etc. The credits occupied by practical teaching in most colleges and universities only account for $15 \%$ of the total credits, leading to logistics management majors The credits of the practical courses are low, and it is difficult to attract the attention of students, so that it is impossible to cultivate students' innovative ability and application ability.

\subsection{Disconnect between supply and demand}

Nowadays, the society's demand for logistics management talents is increasing. At the same time, the skills and knowledge reserves of logistics talents are also expanding. Companies require talents to be familiar with operations such as procurement, distribution, warehousing, processes, and practices, and With the ability to coordinate and handle emergencies, as a whole, enterprises need applied logistics management talents. Nowadays, logistics management majors in colleges and universities focus more on academic education, while neglecting the training of students' practical skills ${ }^{[1]}$.

\subsection{Insufficient course equipment}

Nowadays, hardware devices such as readers, radio frequency identification cards, label shelves, etc. are needed in the logistics management process. However, due to the lack of corresponding equipment in the logistics management majors of colleges and universities, it is impossible to smoothly carry out the cognitive teaching and operation teaching of hardware equipment. Therefore, most of the practical courses in logistics management majors in colleges and universities are based on simulation teaching, and it is impossible for students to participate in the operational learning of Copyright $\odot 2020$ Yujie Zuo

doi: $10.18282 /$ le.v9i6.1336

This is an open-access article distributed under the terms of the Creative Commons Attribution Non-Commercial License

(http://creativecommons.org/licenses/by-nc/4.0/), which permits unrestricted non-commercial use, distribution, and reproduction in any medium, provided the original work is properly cited. 
logistics processes. Nowadays, science and technology are constantly developing, and smarter logistics models are gradually recognized by the majority of enterprises. However, high-tech equipment such as automatic storage equipment and robotic storage will be used in the implementation of intelligent logistics. Because these equipment are expensive, universities have limited funds It cannot be purchased, so teachers of logistics management can only introduce the characteristics and usage of these equipment to students through videos, so that students cannot truly master the application of logistics intelligent technology.

\section{Teaching reform measures for logistics management majors in applied universities under the supply-side reform}

\subsection{Deepen the full integration of production and education}

The development of applied logistics management specialty in colleges and universities must be based on school-enterprise cooperation and the integration of production and education. The combination of production and education is a weak link of the logistics management specialty of colleges and universities. To comprehensively improve the mechanism of combining production and education, colleges and universities need to establish logistics practice bases. Integrate with enterprises, provide consulting services for enterprises, and appropriately organize the experiences learned in enterprises, and integrate them into curriculum research for students to learn. For example, colleges and universities create off-campus internship bases and let the skinny technicians of logistics companies come to the training base to give lectures, so that students can understand the development needs of the industry and talents. In the process of practical teaching, colleges and universities can even invite companies to participate in the training base. To set up practical content, students learn comprehensively in the school, and during the graduation internship stage of students, they can enter the enterprise for rotation internship, so as to comprehensively cultivate students' abilities and lay the foundation for cultivating applied talents.

\subsection{Establish a practical teaching system}

Universities can invite logistics companies to participate in the process of establishing a practical teaching system, which mainly includes three aspects: professional cognition layer, business operation layer, and comprehensive application layer. The first professional cognition layer is mainly by leading students to visit logistics companies and inviting logistics enterprise talents to give lectures in our colleges and universities, through these methods to comprehensively enhance students' cognition level ${ }^{[2]}$; the second business operation layer, mainly including procurement, Warehousing, transportation, supply and other operations. According to these operations, the corresponding training tasks are carried out, so that students can fully understand the operation points of each process of the logistics system; the three comprehensive application layers are mainly to train students through training projects and graduation projects. The ability to solve professional knowledge of logistics management, students will encounter various problems in the process of logistics management, so it is imperative to cultivate students' comprehensive application ability.

\subsection{Establish a teaching evaluation system}

The logistics management major of colleges and universities lacks a teaching evaluation system in the course of practical teaching. Nowadays, most teachers of logistics management mainly evaluate students based on their scores, and students' scores can only determine the students' theoretical knowledge learning situation, not Explain the level of students' practical ability. For example, although most students have completed the assessment of theoretical knowledge, they are still not clear about the practical process. Therefore, colleges and universities need to establish a planned evaluation system that not only evaluates students' theoretical ability, but also evaluates students' resource development, thinking innovation, and case studies. Analysis, teaching design and other abilities, through student self-evaluation or mutual evaluation, teacher evaluation, etc., to comprehensively evaluate the comprehensive ability of students, so that students can find their own shortcomings, so as to further improve the defective part ${ }^{[3]}$.

\subsection{Construction of professional teaching staff}

The practical teaching of logistics management in colleges and universities needs to be carried out by professional teachers. Therefore, colleges and universities need to establish an excellent teaching staff based on the characteristics of 
logistics management. In addition to paying attention to the academic ability and theoretical knowledge of teachers, it is more important Pay attention to teachers' practical teaching experience, and fundamentally improve teachers' practical ability ${ }^{[4]}$. For example, when colleges and universities purchase logistics hardware equipment, they can allow businesses to train teachers and require teachers to understand and be familiar with the entire operation of the equipment. This can fully enhance teachers' practical ability and universities can also encourage teachers to participate in logistics skills training and seminars. At the conference, we will exchange practical teaching experience with experienced logistics management teachers from other universities. At the same time, universities should encourage teachers to enter the enterprise for learning, so as to effectively improve their practical operation ability and design ability.

\section{Concluding remarks}

In the context of higher education, the reason for the supply-side reform is to better meet the development needs of the society and talents. The implementation of reforms in the training of applied talents within colleges and universities requires a comprehensive adjustment of talent training programs, and fundamentally Improve the quality of talent training. In general, in the supply-side reform process of logistics management professional talent training in applied universities, it is necessary to fully understand the training objectives, platforms, facilities, courses, and teachers, etc., and make effective adjustments and allocations to innovate talents. Cultivate the supply system and cultivate a batch of applied logistics management talents for the society.

\section{References}

1. Yao Mengjiao, Yu Bin. An analysis of talent training in applied universities from the perspective of supply-side reform[J]. Education Modernization, 2017, 4(24): 14-15.

2. Liu Ruifen. Research on the lean management of applied university assets under the background of education supplyside reform[J]. Journal of Shandong Institute of Agricultural Engineering, 2020, 37(2): 72-74.

3. Chen Xijian, Liang Jianmei, Chen Yingjun. Exploration and Practice of Innovation and Entrepreneurship Education in Applied Undergraduate Colleges from the Perspective of Supply-side Reform—-Taking Zhaoqing University as an Example [J]. Applied Higher Education Research, 2018, 3(2) ): 42-47.

4. Guo Yi. Focus on supply-side reforms and cultivate applied talents in logistics management in universities[J]. Culture and Education Data, 2019, (27): 117-118,146. 